\title{
STUDENTS' PERCEPTION TOWARDS ENGLISH TEACHER PERFORMANCE IN TEACHING ENGLISH AT THE EIGHTH GRADE OF SMPN 6 LUBUK BASUNG
}

\author{
Melisa Agustin; Melyann Melani; Irwandi Nashir \\ State Institute of Islamic Studies (IAIN), Bukittinggi \\ melisaagustin3008@gmail.com, melyannmelani@iainbukittinggi.ac.id, irwandimalin@gmail.com
}

\begin{abstract}
This research is aimed to find out the students' perception towards English teacher performance in teaching English at the eighth grade. Design of this research is survey quantitative research. The instrument of this research is questionnaire. The data was collected from questionnaire to find out the English teacher performance in teaching English based on preliminary activity, core activity, and closing activity. The technique of data analysis in this research is (1) collecting the student's questionnaire, (2) calculating the percentage of the data, (3) the finding mean of the data, (4) categorizing the perception based on table interpretation. There are five options in answering the questionnaire. Those are strongly agree, agree, neutral, disagree, and strongly disagree. The result showed that the percentage of score students' perception in teaching performance in preliminary activity aspect is $78,8 \%$. It means that students had perception in good category. Besides, the percentage score of students' perceptions in core activity is $76,6 \%$, it means that the students had perception in good category. In addition, the third aspect of performance is closing activity, students had perception with score $73,7 \%$, it means the students perception in closing activity was good category. In conclusion, the data above was gotten students had good perception about English teacher performance in teaching English.
\end{abstract}

Keywords: Perception, english teacher, performance

\section{INTRODUCTION}

Teacher have a necessary role to determine the success of the learning process in the classroom. Teacher did not only to provide subject matter for the students, but teacher should provide the simple in teaching material to make students more understanding on learning process. The teachers' role can be recognized from how the teacher implements the roles. To become a professional teacher, a teacher must achieve a good performance. So that, the teachers' role as an educator can be achieved optimally.

Harmer states that, "performance also describe of the teacher role and might be criticized for the very transmissive and teacher cantered method behaviour it demonstrated. It means that, the teacher should show the role and how the teacher behaviour in teaching classroom. Every teacher has distinct performance in teaching classroom, as well as English teacher in the world. 
The differences make teachers have own characteristics of the other teachers and easy to remember and recognize.

Teachers' performance in learning become the crucial part in supporting the certain of educational process effectively, especially in building the attitude of discipline and the quality of student learning outcomes. In order to work well with different roles, teachers need to establish an appropriate relationship with the students, because teacher as motivator should give the motivation to the learners. Motivator refers to an effort to maintain students' interest by stimulating students' intrinsic motivation. It includes setting a personal example with teachers' behavior, presenting the task properly, developing a good relationship with the learner, increasing learner's linguistic self-confidence, and creating an interesting language class. (Kardena, 2015). Teacher need to spend time making sure that teacher make a class where there is positive, enjoyable and respectful relationship between teacher and students. Additionally, teachers' performance is the ability to perform the teaching and learning activities in a classroom. And teachers' ability in conducting the task of teaching in school as well as possible in order to improve students' learning outcomes. The teachers' performance can be interpreted as a condition that shows teachers' ability in doing duties at school and illustrates the existence of an act displayed, by the teacher during the learning activities.

Teacher performance is teachers' ability to functions effectively of teaching performance in explaining the tasks with high skills and effort with regards to the subject matter using a pedagogical content that leads the students' understanding and effective learning. Teacher who has good performance and professional in implementing of curriculum have some aspects which relate closely to a good teacher performance (Supardi, 2014). There are three aspect of teachers' performance to perform the teachers' responsibilities in teaching effectively, those are designing learning program, implementing of learning process, assessing students learning outcomes.

The first aspect of performance is designing learning programs. Planning of the lesson is an activity which will be done before the learning process is doing in the class. In planning of the lesson, teachers required to make the lesson plan which a several elements in lesson plan, those are: statements of the formulation of learning objectives, the difficulty of learning goal level, fill out of the relevant material, testing students towards the material, concepts and necessity, choosing the variety method, choosing the suitable material, and evaluating student's work. The second aspect is implementing of learning process. Implementing of learning process which based on standard process for elementary and secondary education units includes: preliminary activities, core activities and closing activity. Those aspects are necessary for the teacher to arrange the lesson plan. It means that, in implementing of learning process teacher will be started from the preliminary activity to engage the student's prior knowledge until closing activity. Lastly aspect is assessing the learning outcomes of learners. To assess the student's learning outcomes, the teacher can start to assess preliminary activity, core activity, and closing activity. To assess student's learning outcomes should be done continuously, it aimed to monitor the student's learning process and progress to improve the effectiveness of learning activities 
There are two types of perception, those are positive perception is perception that describes all knowledge and the responses that continue with the effort of its utilization and negative perceptions are perceptions that describes all knowledge and responses that don't aligned with object in perception (Irwanto, 2002). Perception can be grouped by people into different actions. If someone against in negative, may be their action will be negative. If the student's perception is positive, it may act the same. Teacher must be recognized the teachers' role in teaching, especially performance in teaching English. The students' perception of teachers' performance in teaching English will determine competencies of teacher. Students' perception has necessary implications in behavior to determine how students' behave and interact toward the perceived object. For instance, when the teacher only teaches while sitting, it will cause negative perception by students on teachers' performance. Teachers' performance will impact the students' achievements. It will also influence different students' perception toward teachers' performance in teaching English.

Every people have different perception about something. The differences perception of individual with each other is like one object, but other people do not like the object. Montague said that student's perception is the student feeling about something. It means that students can have perception about anything object in learning. For example, students have perception about how the teachers' performance, or about the friends and their lesson. It is important for students to have a good perception about the teacher, because it affects the students behavior. From the experts above, perception is opinion about something. It can affect toward someone feels about something. Teacher performance is the teacher ability in conducting the teaching tasks in the classroom, and teacher must have responsibility to improve student's learning achievements. The level of performance is not only considered from teaching style and behavior, but also how the teachers show the performance. English teachers' performance is the ability of the teacher to impart the relevant skills, knowledge using appropriate methods consistently over time to enhance students' achievements in learning process (Supardi, 2014). Especially performance in teaching English. The students' perception of teachers' performance in teaching English will determine competencies of teacher. Students' perception has necessary implications in behavior to determine how students' behave and interact toward the perceived object. For instance, when the teacher only teaches while sitting, it will cause negative perception by students on teachers' performance. Teachers' performance will impact the students' achievements. It will also influence different students' perception toward teachers' performance in teaching English.

Good performance of teachers can create the effectiveness of learning can make the discipline to students, school and teacher. Therefore, teacher performance can be interpreted as a condition that shows the ability of a teacher to doing tasks in school and describes how an action is displayed by the teacher during learning activities (Supardi, 2014). The researcher chosen SMPN 6 Lubuk Basung to conduct the research because only these school accepted the researcher to hold the study. where there were two schools which were proposed to be target schools. The Headmaster and teachers were allowed the researcher to conduct the preliminary 
research at SMPN 6 Lubuk Basung, because there is no researcher who examined how students' perceptions on the English teacher performance in the school.

Based on the preliminary research by observation and interview on April, $10^{\text {th }} 2019$ at the eighth grade in SMPN 6 Lubuk Basung, it found that there were several problems related to the English teacher performance. First problem, it found by observation and interview of student's eight grade that the teacher only used picture in learning process. Some students said that did not focus to pay attention see the picture, but the other students not problem with the picture and keep focused on the teacher's explanation. The second problem appeared that by the observation, teacher did not engage students' prior knowledge, but the teacher only focused on the learning material. Some of students said that the teacher good in teaching and students like how the way teachers was teaches, when students did not understand about the material, teacher would try to explain again the learning material until students more understand. But other students said that, the teacher did not care toward students understanding, because teacher was focused to continue explain the learning material. Based on fact above, it was important to conduct this research because the English teacher performance was important to improve students' achievements, and students' social attitude. From this research, it would help the teacher find out about the students' perception about teacher performance which might improvecompetencies of teacher. The research will conduct as survey quantitative research about the students' perception toward English teacher performance. It would be covered in the research by the title "The Students' Perception toward English Teacher Performance in Teaching English at the eight Grade in SMP N 6 Lubuk Basung.

\section{METHOD}

The design of this research was survey research. Creswell (2012) stated that survey research are procedures in quantitative research in which investigator administer a survey to a sample or to the entire population of people to describe the attitudes, opinions, behaviors, or characteristics of the population. According to Gay, Mills, and Airasian (2000), survey research involves collecting data on test hypotheses to answer questions about people's opinions on some topics or issues. It means that to measure students' perception the researcher needs to quantitative research uses the data shape of the numbers and statistic analyze to answer question about peoples' opinions.

Table 1. Research Guideline by Supardi (2014)

\begin{tabular}{|c|l|l|l|}
\hline Variable & Indicators & \multicolumn{1}{c|}{ Sub Indicators } & Description \\
\hline $\begin{array}{c}\text { The Students' } \\
\text { Perception Towards } \\
\begin{array}{c}\text { English Teacher } \\
\text { Performance in } \\
\text { Teaching English }\end{array}\end{array}$ & $\begin{array}{c}\text { 1. Preliminary } \\
\text { Activity }\end{array}$ & $\begin{array}{l}1.1 \text { Preparing the students both } \\
\text { psychologically and physically to } \\
\text { follow instruction process. }\end{array}$ & $\begin{array}{c}1.1 .1 \text { Teacher prepares the students } \\
\text { both psychological and physical } \\
\text { before starting the lesson. } \\
1.1 .2 \text { Teacher checks the student's } \\
\text { attendance before starting lesson. }\end{array}$ \\
\hline
\end{tabular}




\begin{tabular}{|c|c|c|}
\hline & $\begin{array}{l}1.2 \text { Asking questions relating to the } \\
\text { students' background knowledge } \\
\text { and the learning material which } \\
\text { will be learned. }\end{array}$ & $\begin{array}{l}\text { 1.2.1 Teacher relates the previous } \\
\text { learning material with the } \\
\text { material that will be learned. } \\
\text { 1.2.2 The teacher relates learning } \\
\text { material by telling an interesting } \\
\text { thing about real life } \\
\text { 1.2.3Teacher gives example in } \\
\text { order to make students easy to } \\
\text { understand the material. }\end{array}$ \\
\hline \multirow[t]{4}{*}{ 2. Core Activity } & $\begin{array}{l}\text { 1.3 Explaining the learning goals or } \\
\text { the desired competence. } \\
1.4 \text { Stating the learning material } \\
\text { coverage and explaining the } \\
\text { description of learning activity } \\
\text { according to syllabus. }\end{array}$ & $\begin{array}{l}\text { 1.3.1 Teacher states the learning } \\
\text { goals. } \\
\text { 1.4.1 Teacher delivers the } \\
\text { sequences of learning activity and } \\
\text { the explanation of activity } \\
\text { description according to syllabus. }\end{array}$ \\
\hline & 2.1 Exploration & $\begin{array}{l}\text { 2.1.1. Teacher develops student's } \\
\text { skill to manage the information } \\
\text { about material that will be } \\
\text { learned. } \\
2.1 .2 \text { Teacher uses various } \\
\text { teaching method during teaching } \\
\text { process. } \\
2.1 .3 \text {. Teacher emerge the } \\
\text { student's creativity to active } \\
\text { during learning activity. }\end{array}$ \\
\hline & 2.2 Elaboration & $\begin{array}{l}\text { 2.2.1 Teacher develop student's } \\
\text { skill to read and write through } \\
\text { certain tasks. } \\
\text { 2.2.2 Teacher give the students } \\
\text { opportunities to ask questions. } \\
\text { 2.2.3 Teacher create fun learning } \\
\text { environment. }\end{array}$ \\
\hline & 2.3 Confirmation & $\begin{array}{l}\text { 2.3.1 Teacher gives positive } \\
\text { feedback to the student's } \\
\text { achievements. } \\
\text { 2.3.2 Teacher gives praise or } \\
\text { reward to the student's } \\
\text { achievements. } \\
\text { 2.3.3 Teacher gives confirmation } \\
\text { to students through smiling, nod, } \\
\text { clap to the student's } \\
\text { achievements. }\end{array}$ \\
\hline \multirow[t]{2}{*}{$\begin{array}{l}\text { 3. } \\
\text { Activity }\end{array}$} & $\begin{array}{l}\text { 3.1 Together with students or did } \\
\text { by teacher to make summary or } \\
\text { learning conclusion. }\end{array}$ & $\begin{array}{l}\text { 3.1.1 Teacher concludes learning } \\
\text { at the end of learning process. } \\
\text { 3.1.2 Teacher uses the learning } \\
\text { time with effective. }\end{array}$ \\
\hline & $\begin{array}{l}3.2 \text { Doing assessment or } \\
\text { consistent reflection toward the } \\
\text { activity which already did which } \\
\text { already programmed. }\end{array}$ & $\begin{array}{l}\text { 3.2.1 Teacher give the task about } \\
\text { the material with already learned. } \\
\text { 3.2.2 Teacher gives homework } \\
\text { the task about the material which } \\
\text { already learned. } \\
\text { 3.2.3 Teacher does assessment to } \\
\text { the result of learning activities } \\
\text { which already did. }\end{array}$ \\
\hline
\end{tabular}




\begin{tabular}{|l|l|l|l|}
\hline & $\begin{array}{l}3.3 \text { Giving feedback to the process } \\
\text { and learning result }\end{array}$ & $\begin{array}{l}\text { 3.3.1 Teacher gives feedback to } \\
\text { the students toward the process } \\
\text { and the learning result. } \\
3.3 .2 \text { Teacher asks student's } \\
\text { opinion about the material which } \\
\text { already learned. }\end{array}$ \\
\hline & $\begin{array}{l}\text { 3.4 Planning the action as respond } \\
\text { to students learning result in form } \\
\text { of remedial, enrichment, } \\
\text { counseling, or giving individual or } \\
\text { group task according to students } \\
\text { learning result and telling lesson } \\
\text { plan for next learning process. }\end{array}$ & $\begin{array}{l}\text { language by the students. } \\
\text { plandable the next meeting. }\end{array}$ \\
\hline
\end{tabular}

In this research, the researcher used total sampling to collect the data respondents. This research focus at the eighth grade of SMPN 6 Lubuk Basung which consist of 86 students. In this research, the students asked for response questionnaire. The statement consists of 25 items with positive perception and negative statements. The questionnaire is used to find what the description of students' perception is and the questionnaire in form of Indonesian language because to make sure the informant easy to understand the statements. The researcher used the content validity. That content validity is referring to an instrument that has a content suitability to measure (Margono, 1997). It means that, the researcher should do validity to judge the questionnaire is valid y consulting the content to the expert.

In collecting students' perception result, the researcher gave a questionnaire to students of the eighth grade in SMPN 6 Lubuk Basung. The step to collect the data will be as follow: research gave a questionnaire to students, students' response to the question are being statically analyzed, the researchers collected the questionnaire after students' answer it. The analysis of data would do at the end of the research. This data analyzed by using formula that stated by Morissan (2015) which was used to describe a data to a single variable or question on instruments. After getting the data, the researchers analyzed the students' answer by Likert Scale, suggested by Morissan that Likert Scale is aimed to measure perception toward another.

Table 2. Rating Likert Scale

\begin{tabular}{|c|c|c|c|}
\hline \multirow{2}{*}{ Respond } & \multirow{2}{*}{ Code } & \multicolumn{2}{|c|}{ Type of Statement } \\
\cline { 3 - 4 } & & Positive & Negative \\
\hline Strongly Agree & SS & 5 & 1 \\
\hline Agree & ST & 4 & 2 \\
\hline Neutral & N & 3 & 3 \\
\hline Disagree & TS & 2 & 4 \\
\hline Strongly Disagree & STS & 1 & 5 \\
\hline
\end{tabular}

In this research, the researcher describes about questionnaire before students answering the question. Researcher describe about criteria of score if students answer it. The question that researcher gave to student is related with the problem about English teacher performance on 
students perception. After getting the data, the researcher describes the data. In describing the data of students' perception toward English teacher performance in teaching English, the researcher follows this following step: Collecting of students' questionnaire, Calculating of percentage of the data. The technique of analyzing the data in this research is percentage techniques by using the formula that suggested by Sudijono (1987) as follow:

$$
\begin{aligned}
& P=\frac{f}{n} \times 100 \\
& P=\text { the percentage of the result } \\
& f=\text { the percentage of answer on each question } \\
& n=\text { the total amount of the sample }
\end{aligned}
$$

Next, the finding mean of the data by using formula that suggested by Morissan (2015) as follow:

$$
\begin{aligned}
& M x=\frac{\Sigma x}{N} \\
& M x=\text { Mean } \\
& \Sigma x=\text { Total of percentage } \\
& N=\text { Number of cases }
\end{aligned}
$$

Next the researcher categorizes English teacher's performance in the table category of the students to answer research question. Categorizing the Perception based on Arikunto's criteria (2010):

Table 3. The Data Interpretation of Rating Quality

\begin{tabular}{|c|c|}
\hline The Range of Category & Interpretation \\
\hline $81 \%-100 \%$ & Very Good \\
\hline $61 \%-80 \%$ & Good \\
\hline $41 \%-60 \%$ & Enough \\
\hline $21 \%-40 \%$ & Low \\
\hline$>20 \%$ & Very Low \\
\hline
\end{tabular}

\section{FINDINGS AND DISCUSSION}

The item of the question answered by the students then calculated into table and chart to know the description and percentage of the students' perception toward English teacher performance in teaching English.

According to the students' answered for questionnaire form, there are 25 questions for students' perception towards English teacher performance in teaching English. The diagram below showed the percentage of three aspects and each aspect with different level of frequency. The description of the data about the students' perception toward English teacher performance in teaching English at the eighth grade in SMPN 6 Lubuk Basung are as follow: 


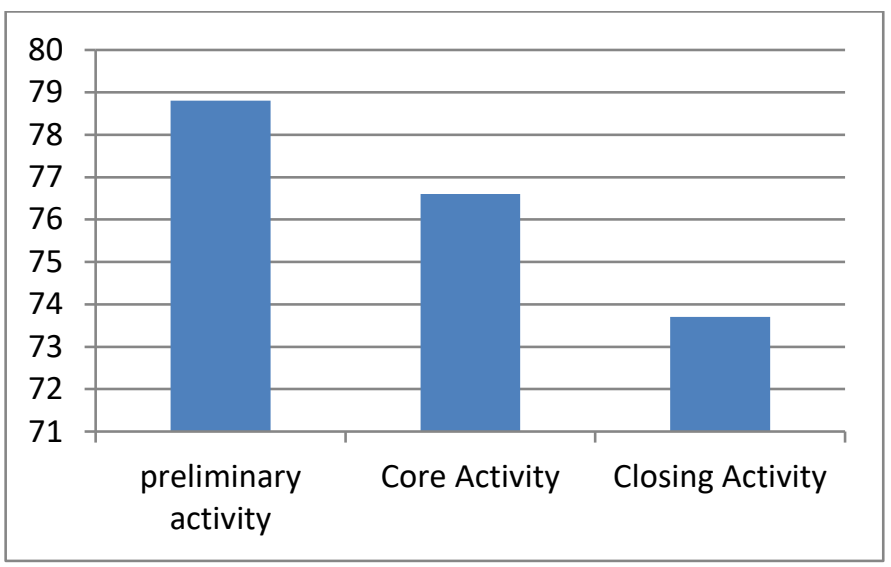

Figure 1. Mean Percentage of Students' Answer

The figure above explained the total percentage of the students' perception toward english teacher performance in teaching english. The highest aspect that was choosen preliminary activity (78,8\%), core activity (76,6\%), and closing activity (73,7\%). The students' perception toward English teacher performance was gotten positive perception, because among of indicator has good category. It means that students has positive perception toward english teacher performance in teaching english. The percentage was gotten by finding the average of each process choosen by the students. The total percentage above would be revealed further in the analysis of the data. For more detail description in each frequency, the chart above divide frequencies into strongly agree, agree, neutral, disagree, strongly disagree.

Based on the interpretation of the percentage in the figure, preliminary activity, and core activity was good category and closing activity was enough category, it means positive perception.

Table 5. The Result of Students' Perception Toward English Teacher Performance in All Indicators

\begin{tabular}{|c|c|c|c|c|}
\hline No. & Statement & Answer & Frequency & $\begin{array}{l}\text { Percentage of } \\
\text { Item }\end{array}$ \\
\hline \multirow[t]{5}{*}{1} & \multirow{5}{*}{$\begin{array}{l}\text { I think the teacher always prepares a } \\
\text { quiet classroom atmosphere before } \\
\text { starting lessons. }\end{array}$} & Strongly Agree & 38 & $44,2 \%$ \\
\hline & & Agree & 35 & $40,7 \%$ \\
\hline & & Neutral & 11 & $12,8 \%$ \\
\hline & & Disagree & 2 & $2,3 \%$ \\
\hline & & Strongly Disagree & 0 & $0 \%$ \\
\hline \multirow[t]{5}{*}{2} & \multirow{5}{*}{$\begin{array}{l}\text { I think the teacher always checks the } \\
\text { attendance of students before starting } \\
\text { learning. }\end{array}$} & Strongly Agree & 16 & $18,6 \%$ \\
\hline & & Agree & 49 & $57 \%$ \\
\hline & & Neutral & 13 & $15,1 \%$ \\
\hline & & Disagree & 8 & $9,3 \%$ \\
\hline & & Strongly Disagree & 0 & $0 \%$ \\
\hline \multirow[t]{5}{*}{3} & \multirow{5}{*}{$\begin{array}{l}\text { I like the teachers who associate past } \\
\text { subject matter with the material to be } \\
\text { studied. }\end{array}$} & Strongly Agree & 26 & $30,3 \%$ \\
\hline & & Agree & 40 & $46,5 \%$ \\
\hline & & Neutral & 17 & $19,8 \%$ \\
\hline & & Disagree & 3 & $3,4 \%$ \\
\hline & & Strongly & 0 & $0 \%$ \\
\hline
\end{tabular}




\begin{tabular}{|c|c|c|c|c|}
\hline & & Disagree & & \\
\hline \multirow[t]{5}{*}{4} & \multirow{5}{*}{$\begin{array}{l}\text { I like the teacher to associate the } \\
\text { material with telling stories of } \\
\text { interesting and real-life things. }\end{array}$} & Strongly Agree & 26 & $30,2 \%$ \\
\hline & & Agree & 40 & $46,5 \%$ \\
\hline & & Neutral & 12 & $14 \%$ \\
\hline & & Disagree & 6 & $7 \%$ \\
\hline & & Strongly Disagree & 2 & $2,3 \%$ \\
\hline \multirow[t]{5}{*}{5} & \multirow{5}{*}{$\begin{array}{l}\text { I think the teacher provides an example } \\
\text { that is easy to understand using the } \\
\text { media. }\end{array}$} & Strongly Agree & 25 & $29,1 \%$ \\
\hline & & Agree & 38 & $44,2 \%$ \\
\hline & & Neutral & 20 & $23,4 \%$ \\
\hline & & Disagree & 3 & $3,5 \%$ \\
\hline & & $\begin{array}{l}\text { Strongly } \\
\text { Disagree }\end{array}$ & 0 & $0 \%$ \\
\hline \multirow[t]{5}{*}{6} & \multirow{5}{*}{$\begin{array}{l}\text { In my opinion, teachers never convey } \\
\text { learning objectives before discussing } \\
\text { the material to be studied. }\end{array}$} & Strongly Agree & 8 & $9,3 \%$ \\
\hline & & Agree & 16 & $18,6 \%$ \\
\hline & & Neutral & 22 & $25,6 \%$ \\
\hline & & Disagree & 31 & $36 \%$ \\
\hline & & Strongly Disagree & 9 & $10,5 \%$ \\
\hline \multirow[t]{5}{*}{7} & \multirow{5}{*}{$\begin{array}{l}\text { I think the teacher conveys a series of } \\
\text { learning activities before starting } \\
\text { learning. }\end{array}$} & Strongly Agree & 35 & $40,7 \%$ \\
\hline & & Agree & 42 & $48,8 \%$ \\
\hline & & Neutral & 8 & $9,3 \%$ \\
\hline & & Disagree & 1 & $1,2 \%$ \\
\hline & & Strongly Disagree & 0 & $0 \%$ \\
\hline \multirow[t]{5}{*}{8} & \multirow{5}{*}{$\begin{array}{l}\text { I tend not to like teachers teaching in } \\
\text { the same way. }\end{array}$} & Strongly Agree & 19 & $22,1 \%$ \\
\hline & & Agree & 26 & $30,2 \%$ \\
\hline & & Neutral & 11 & $12,8 \%$ \\
\hline & & Disagree & 9 & $22,1 \%$ \\
\hline & & Strongly Disagree & 11 & $12,8 \%$ \\
\hline \multirow[t]{5}{*}{9} & \multirow{5}{*}{$\begin{array}{l}\text { I feel that the teacher always uses media } \\
\text { that does not vary in every meeting. }\end{array}$} & Strongly Agree & 24 & $27,9 \%$ \\
\hline & & Agree & 19 & $22,1 \%$ \\
\hline & & Neutral & 13 & $15,1 \%$ \\
\hline & & Disagree & 16 & $18,6 \%$ \\
\hline & & Strongly Disagree & 14 & $16,3 \%$ \\
\hline \multirow[t]{5}{*}{10} & \multirow{5}{*}{$\begin{array}{l}\text { It is fun if the teacher invites students to } \\
\text { be active in the class. }\end{array}$} & Strongly Agree & 34 & $39,5 \%$ \\
\hline & & Agree & 33 & $38,4 \%$ \\
\hline & & Neutral & 17 & $19,8 \%$ \\
\hline & & Disagree & 2 & $2,3 \%$ \\
\hline & & Strongly Disagree & 0 & $0 \%$ \\
\hline \multirow[t]{5}{*}{11} & \multirow{5}{*}{$\begin{array}{l}\text { I feel excited when the teacher gives } \\
\text { assignments about the material being } \\
\text { studied. }\end{array}$} & Strongly Agree & 27 & $31,4 \%$ \\
\hline & & Agree & 43 & $\mathbf{5 0 \%}$ \\
\hline & & Neutral & 16 & $18,6 \%$ \\
\hline & & Disagree & 0 & $0 \%$ \\
\hline & & Strongly Disagree & 0 & $0 \%$ \\
\hline \multirow[t]{5}{*}{12} & \multirow{5}{*}{$\begin{array}{l}\text { I like that teachers give students the } \\
\text { opportunity to ask questions. }\end{array}$} & Strongly Agree & 32 & $37,2 \%$ \\
\hline & & Agree & 36 & $41,9 \%$ \\
\hline & & Neutral & 17 & $19,8 \%$ \\
\hline & & Disagree & 1 & $1,1 \%$ \\
\hline & & Strongly Disagree & 0 & $0 \%$ \\
\hline \multirow[t]{5}{*}{13} & \multirow{5}{*}{$\begin{array}{l}\text { I feel excited when the teacher invites } \\
\text { students to play games between lessons. }\end{array}$} & Strongly Agree & 21 & $24,4 \%$ \\
\hline & & Agree & 40 & $46,5 \%$ \\
\hline & & Neutral & 19 & $22,1 \%$ \\
\hline & & Disagree & 3 & $3,5 \%$ \\
\hline & & Strongly Disagree & 3 & $3,5 \%$ \\
\hline
\end{tabular}




\begin{tabular}{|c|c|c|c|c|}
\hline \multirow[t]{5}{*}{14} & \multirow{5}{*}{$\begin{array}{l}\text { I like teachers rewarding student } \\
\text { success. }\end{array}$} & Strongly Agree & 30 & $34,9 \%$ \\
\hline & & Agree & 40 & $46,5 \%$ \\
\hline & & Neutral & 9 & $10,5 \%$ \\
\hline & & Disagree & 4 & $4,6 \%$ \\
\hline & & Strongly Disagree & 3 & $3,5 \%$ \\
\hline \multirow[t]{5}{*}{15} & \multirow{5}{*}{$\begin{array}{l}\text { I like teachers to give praise such as } \\
\text { "good job, excellent, nice". }\end{array}$} & Strongly Agree & 48 & $55,8 \%$ \\
\hline & & Agree & 32 & $37,2 \%$ \\
\hline & & Neutral & 4 & $4,6 \%$ \\
\hline & & Disagree & 1 & $1,2 \%$ \\
\hline & & Strongly Disagree & 1 & $1,2 \%$ \\
\hline \multirow[t]{5}{*}{16} & \multirow{5}{*}{$\begin{array}{l}\text { It would be nice if the teacher smiled, } \\
\text { nodded, and applauded student } \\
\text { achievement. }\end{array}$} & Strongly Agree & 38 & $44,2 \%$ \\
\hline & & Agree & 28 & $32,5 \%$ \\
\hline & & Neutral & 12 & $14 \%$ \\
\hline & & Disagree & 6 & $7 \%$ \\
\hline & & Strongly Disagree & 2 & $2,3 \%$ \\
\hline \multirow[t]{5}{*}{17} & \multirow{5}{*}{$\begin{array}{l}\text { I think teachers tend to rarely conclude } \\
\text { the subject matter. }\end{array}$} & Strongly Agree & 14 & $16,3 \%$ \\
\hline & & Agree & 14 & $16,3 \%$ \\
\hline & & Neutral & 19 & $22,1 \%$ \\
\hline & & Disagree & 9 & $22,1 \%$ \\
\hline & & Strongly Disagree & 20 & $23,2 \%$ \\
\hline \multirow[t]{5}{*}{18} & \multirow{5}{*}{$\begin{array}{l}\text { In my opinion, teachers tend to rarely } \\
\text { use the learning time on time. }\end{array}$} & Strongly Agree & 11 & $12,7 \%$ \\
\hline & & Agree & 20 & $23,3 \%$ \\
\hline & & Neutral & 20 & $23,3 \%$ \\
\hline & & Disagree & 20 & $23,3 \%$ \\
\hline & & Strongly Disagree & 15 & $17,4 \%$ \\
\hline \multirow[t]{5}{*}{19} & \multirow{5}{*}{$\begin{array}{l}\text { I tend to be excited when the teacher } \\
\text { gives a final project with the material } \\
\text { that has been studied. }\end{array}$} & Strongly Agree & 19 & $22,1 \%$ \\
\hline & & Agree & 35 & $40,7 \%$ \\
\hline & & Neutral & 21 & $24,4 \%$ \\
\hline & & Disagree & 10 & $11,6 \%$ \\
\hline & & Strongly Disagree & 1 & $1,2 \%$ \\
\hline \multirow[t]{5}{*}{20} & \multirow{5}{*}{$\begin{array}{l}\text { It is fun when the teacher gives } \\
\text { homework }(\mathrm{HW}) \text {. }\end{array}$} & Strongly Agree & 25 & $29,1 \%$ \\
\hline & & Agree & 36 & $41,9 \%$ \\
\hline & & Neutral & 16 & $18,6 \%$ \\
\hline & & Disagree & 7 & $8,1 \%$ \\
\hline & & Strongly Disagree & 2 & $2,3 \%$ \\
\hline \multirow[t]{5}{*}{21} & \multirow{5}{*}{$\begin{array}{l}\text { In my opinion, teachers rarely give an } \\
\text { assessment at the end of the lesson. }\end{array}$} & Strongly Agree & 6 & $7 \%$ \\
\hline & & Agree & 26 & $30,2 \%$ \\
\hline & & Neutral & 25 & $29,1 \%$ \\
\hline & & Disagree & 21 & $24,4 \%$ \\
\hline & & Strongly Disagree & 8 & $9,3 \%$ \\
\hline \multirow[t]{5}{*}{22} & \multirow{5}{*}{$\begin{array}{l}\text { I tend to prefer to provide motivation } \\
\text { for student progress in the classroom. }\end{array}$} & Strongly Agree & 39 & $45,3 \%$ \\
\hline & & Agree & 35 & $40,7 \%$ \\
\hline & & Neutral & 10 & $11,6 \%$ \\
\hline & & Disagree & 1 & $1,2 \%$ \\
\hline & & Strongly Disagree & 1 & $1,2 \%$ \\
\hline \multirow[t]{5}{*}{23} & \multirow{5}{*}{$\begin{array}{l}\text { I feel excited about the teacher asking } \\
\text { students' opinions about the material } \\
\text { that has been studied. }\end{array}$} & Strongly Agree & 38 & $44,2 \%$ \\
\hline & & Agree & 32 & $37,2 \%$ \\
\hline & & Neutral & 12 & $13,9 \%$ \\
\hline & & Disagree & 4 & $4,7 \%$ \\
\hline & & Strongly Disagree & 0 & $0 \%$ \\
\hline
\end{tabular}




\begin{tabular}{|l|l|c|c|c|}
\hline 24 & It is easier for me to understand if the & Strongly Agree & 28 & $32,5 \%$ \\
\cline { 3 - 4 } & \multirow{2}{*}{\begin{tabular}{l} 
eacher teaches using language that is to understand. \\
\cline { 3 - 4 }
\end{tabular}} & Agree & 38 & $\mathbf{4 4 , 2 \%}$ \\
\cline { 3 - 5 } & & Neutral & 16 & $18,6 \%$ \\
\cline { 3 - 5 } & \multirow{2}{*}{$\begin{array}{l}\text { I think teachers tend to rarely submit } \\
\text { lesson plans for the next meeting. }\end{array}$} & Disagree & 4 & $4,7 \%$ \\
\cline { 3 - 5 } & & Strongly Disagree & 0 & $0 \%$ \\
\cline { 3 - 5 } & & Strongly Agree & 6 & $7 \%$ \\
\cline { 3 - 5 } & & Agree & 19 & $22,1 \%$ \\
\cline { 3 - 5 } & & Strongly Disagree & 29 & $\mathbf{3 3 , 7 \%}$ \\
\hline
\end{tabular}

The table above describe about the students' perception toward english teacher performance in teaching english in all indicators. The highest percentage is on perception number 2 " the teacher checks student's attendance before starting the lesson" in option "agree" with the percentage is $57 \%$. And lowest percentage is on perception number 1 " the teacher prepares the classroom environment before starting the lesson" in option "strongly disagree" with percentage is $0 \%$.

Based on the description and analysis of the data above, there were three findings in the questionnaire. It showed that there were 25 items that answered by 86 students as sample. One statement consists of 5 possible answer they were strongly agree, agree, neutral, disagree, strongly disagree. From the table above can be seen that there were indicators English teacher performance in teaching English. First finding, the mean percentage of about teacher performance in preliminary activity was $78,8 \%$. Based on the percentage gotten, it can be interpreted good on this finding. Supardi mentions that preliminary activity is preparing the students both psychologically and physically to follow instruction process, asking questions relating to the students' background knowledge and the learning material which will be learned, explaining the learning goals or the desired competence, starting the learning material coverage and explaining the description of learning activity according to syllabus. This research proved that preliminary activity is teacher start to teach in the classroom, the teacher should prepare the students to follow the learning process. Teacher can start by giving some information related to material that will be teach by the teacher.

The second finding was about teacher performance in core activity. Teacher implementing the learning models, learning methods, learning media, and learning resources adapted to the characteristics of students and subjects. In core activity, teacher using method which is adapted to the characteristics of students and material. The mean percentage of this finding was $76,6 \%$. It showed that student's perception of this finding was good. Based on theory on the previous chapter, core activity is instruction process to reach the basic competence (KD) which done through interactive, inspiring, challenging, motivating the students so that they have initiative, creativity, and self-confidence according to their talent, interest, physical development, and student's psychological condition. The core activity uses the method which is suitable with students and course characteristic. It includes some activity such as: exploration, elaboration and 
confirmation. so, this activity is how the teacher make sure students to enjoy in the classroom and motivate students and self confidence.

The last finding was teacher performance in closing activity. Closing activity is teacher doing assessment to students activity and teacher invite the student to make the conclusion of learning and give feedback towards students' achievement in learning outcomes. The teacher gives the information about the planning of the lesson on the next meeting. The mean percentage of this finding was $73,7 \%$. It showed that student's perception of this finding was good. The researcher assumed that if teacher performance in closing activity is teacher able to make conclude the activity. Based on theory in previous chapter, teacher performance in closing activity is teacher and students make summary or learning conclusion, doing assessment or consistent reflection toward the activity which already did which already programmed, giving feedback to the process and learning result, planning the action as respond to students learning result in form of remedial, enrichment, counseling, or giving individual or group task according to students learning result and telling lesson plan for next learning process. It means that, closing activity described when teacher making conclusion about the topic material, and plan the lesson for next meeting. Based on the result, the researcher interpreted the highest of mean data percentage into rating quality that suggested by Norman Blaike that divide into five rating quality: very good (80\%-100\%), good (60\%-79,99\%), fair/ good enough (40\%-59,99\%), not good (20\%-39,99\%), very bad (0\%-19,99\%). Based on the findings the data, the researcher made conclusion about the students' perception toward English teacher performance in teaching English at the eighth grade in SMPN 6 Lubuk Basung on the mean percentage of each indicator of English teacher performance in teaching English. By over all, students' perception toward English teacher performance in teaching English at the eighth grade in SMPN 6 Lubuk Basung was tend positive. Most of students "agree" toward three indicators about English teacher performance in teaching English. It can be concluded that students tend to have positive perception toward English teacher performance in teaching English.

\section{CONCLUSIONS}

Based on the finding result of the research discussed in the previous chapter, it can be concluded that in general, the students at the eighth grade of SMPN 6 Lubuk Basung have some perception toward English teacher performance in teaching English. That was concluded by mean score of each aspect. In summary, the researcher showed that the students' perception toward English teacher performance in teaching English at the eighth grade in SMPN 6 Lubuk Basung. First, students' perception toward English teacher performance in preliminary activity was $\mathbf{7 8 , 8 \%}$ in rating quality of good. Based on percentage gotten, it can be interpreted that the students' has good perception on this indicator. Second, students' perception toward English teacher performance in core activity was $\mathbf{7 6 , 6 \%}$ in rating quality of good. Third, students' perception toward English teacher performance in closing activity was $\mathbf{7 3 , 7 \%}$ in rating quality good. By over all, students' perception toward English teacher performance in teaching English at the 
eighth grade in SMPN 6 Lubuk Basung was tend positive. Most of students "agree" toward three indicators about English teacher performance in teaching English. It can be concluded that students tend to have positive perception toward English teacher performance in teaching English.

Based on the finding above, it looked as a consideration for English teacher Performance in teaching English at the eighth grade in SMPN 6 Lubuk Basung. As could be seen on the result of the research, the researcher would like to suggest as follows, the English teacher always increase teachers' performance in teaching English because it will give good impact for students achievements, the English teacher always increase teachers' performance in teaching English because it will give good impact for students achievements, this research is an input or consideration for many people especially who concerns in English education section and other educational institutions, since this research is only a beginning research, so it is still needs more revision and following up discussion, it is hoped to the next researcher to do research in other setting to have variation research as the researcher assumes that this research is conducted in different place, it will give different results.

\section{REFERENCES}

Ali, H., et al. (2018). Persepsi petani terhadap kinerja penyuluh pertanian lapangan di desa talu melito kecamatan telaga biru kabupaten gorontalo. Skripsi. Universitas Gorontalo: Agrinesia.

Arikunto, S. (2010). Prosedur penelitian: Suatu pendekatan praktik. Jakarta:

Creswell, J. W. (2012). Research Design Qualitative, Quantitative, and Mixed Method Approaches. Thousand Oaks, California: SAGE Publications, Inc.

Gay, L. R., Mils., G. E., \& Airasian, P. (2000). Educational research; competencies for analysis and application. Boston: Pearson

Irwanto. (2002). Psikologi umum. PT. Prenhallindo. Jakarta

Kardena, A. (2015). Change of curriculum and its implication on teachers' performance in efl classroom, The State University of Padang, ISELT.

Marliani, R. (2010). Psikologi umum. Yogyakarta: Andi Yogyakarta.

Marjorie, M. (1997). "Student perception, mathematical problem solving, and learning disabilities”. Pennsylvania State Univ, 8(1).

Margono, (1997). Metodologi peneltian pendidikan. Jakarta: PT. Rineka Cipta

Harmer, J. (2007). The practice of english language teaching. New York: Longman, Pearson. 


\section{ELLTER-J}

Vol.2, No.1. April 2021, 33-46

Sudijono, A (1987). Pengantar statistik pendidikan. Jakarta: PT. Raja Grafindo. Persada.

Supardi. (2014). Kinerja guru. Jakarta: PT Raja Grafindo Persada.

Walgito, B. (1980). Pengantar psikologi umum. Yogyakarta: Andi Yogyakarta. 